\title{
DESIGNING A TEACHER TRAINING PROGRAMME FOR CHARACTER EDUCATION: AN INTERNATIONAL PARTNERSHIP
}

\author{
Manuel Joaquín Fernández González \\ University of Latvia, Latvia \\ Tamara Pigozne \\ University of Latvia, Latvia \\ María Verdeja Muñiz \\ University of Oviedo, Spain \\ Egle Säre \\ University of Tartu, Estonia \\ Svetlana Surikova \\ University of Latvia, Latvia
}

\begin{abstract}
There is a need of innovative teacher training programmes for character education. This paper addresses three research questions: What are the challenges that a teacher training programme for character education should address? What are the learning outcomes that the programme should achieve? How should the programme be structured for supporting the achievement of those learning outcomes? Two regional authorities, three schools, three universities and a centre of teacher training from Latvia, Estonia and Spain created a strategic partnership for answering these research questions, using design-based implementation research. The results include six domains of learning outcomes and a programme structure adaptable to different educational context.
\end{abstract}

Keywords: character education, instructional design, learning outcomes, teacher training.

\section{Introduction}

The purpose of education is not only to transfer knowledge to young people but to facilitate the development of their personality (Campbell, 2008; Sanger, 2012; Osguthorpe, 2013). In order to contribute to the fulfilment of this broad purpose, a 'good teacher' needs to possess not only subject knowledge, skills and competences, but also a good character and good sense (Arthur, Davison, \& Lewis, 2005; Carr, 2007; Rosenberg, 2018). However, teachers in general education schools all over Europe are facing the challenge of an overloaded school curriculum focused on knowledge and skills, a lack of time for understanding in depth and developing their own character. 
In a virtue ethics perspective, which is the theoretical background of this paper, character is defined as "a set of personal traits or dispositions that produce specific moral emotions, inform motivation and guide conduct" (The Jubilee Centre, 2017, p. 2). A good character includes the cultivation of intellectual, moral, performance and civic virtues, guided by good sense: the meta-virtue of prudence. Virtues are moral habits that enable human beings to give an appropriate ethical response to situations in any area of experience (p. 3) and that sustain a well-rounded life and a thriving society (p. 5).

During teacher training, pre-service teachers shape their future professional practice and their understanding of their educational role. Most teachers desire to address the ethical dimensions of their work during their training (The Jubilee Centre, 2015) because a teacher training based exclusively on competences will not prepare them for the ethical demands of the role (Arthur et al., 2005). Insufficient attention has been paid to character during teacher's initial teacher education (Arthur, Fullard, Watts, \& Moller, 2018). In a recent investigation involving 369 pre-service teachers in UK, more than $80 \%$ of respondents considered character education to be 'important' or 'very important', but only a minority $(7.7 \%)$ of respondents stated that they were familiar with the term 'character' and that they knew what it meant, and less than 25\% reported that they felt 'very prepared' or 'prepared' to develop the character of the pupils in their classrooms (Arthur et al., 2018).

There is a need of innovative teacher training programmes for character education which adopt innovative approaches and methods for meeting the needs of today's schools and society. Teachers need to be empowered for daring to initiate programmes and elaborating materials for character education at school. Ideally, those materials should be cultural-sensitive, adapted to the concrete educational spaces, school environment sensitive and family inclusive. Schools need teachers who are able to initiate innovative practices for supporting the development of pupils' character and transversal competences. And families increasingly need support from school to transmit values to youngsters in a sustainable way.

Qualitative teacher training in character and virtue education may have a direct positive impact in pupils. Within a context of overloaded school curriculum which focusses on the competitive acquisition of knowledge and skills, pupils need a profound education in values and character development (honesty, commitment, and grit for personal flourishment). Moreover, pupils need support for acquiring and developing the specific transversal skills that underpin innovative behaviour (Chell \& Athayde, 2011), such as self-efficacy (e.g., self-belief, self-assurance, self-awareness) and energy (e.g., drive, motivation, hard work, persistence and commitment). 
For addressing the challenges mentioned above, in 2017 two regional authorities, three schools (two of them as associated partners), three universities and a centre of teacher training from Latvia, Estonia and Spain created a strategic partnership within the Erasmus+ project "Supporting teachers for developing intra-personal competencies and character education at school Arete Catalyst”(in Greek, arete means 'virtue' or 'character excellence'; and a catalyst is an 'activator or facilitator of changes and transformations'). The project aimed at supporting schoolteachers in the development of pupils' intrapersonal competences and character through innovative multifaceted perspectives such as philosophy for children (P4C), education for citizenship, transversal competences and virtues ethics. During the project, an innovative research-based teacher training programme, called "Arete Catalyst", was created, in order to provide teachers the knowledge and skills necessary to promote character education initiatives adapted to needs of their school, embracing the whole school culture, and involving all educational actors: municipalities, school staff, teachers, parents and pupils.

\section{Literature Review}

The initial theoretical framework used for the elaboration of the training programme within the project "Arete Catalyst" was based on the work of the Jubilee Centre for Character and Virtues of the University of Birmingham (The Jubilee Centre, 2015; The Jubilee Centre, 2017). During the preliminary research, this approach was enriched with different perspectives proposed by participants, such as P4C and education for citizenship. Philosophising with children in school age improves learners' self-esteem and has a positive impact on cognitive and reasoning abilities (Sharp, Reed, \& Lipman, 2010). These findings were confirmed by recent studies addressing the implementation of P4C in Estonia (Säre, Luik, \& Tulviste, 2016; Säre, 2018). In the field of education for citizenship, recent research has found that the project 'Support for positive behaviour' (Dreikurs, Grunwald, \& Pepper, 1998; Dreikurs, Cassel, \& Ferguson, 2004) facilitates pupils' positive behaviour and personality development, and contributes to the reduction of behaviour breaches at school (Ogden \& Sørlie, 2009; Daniela, Nīmante, \& Kraǵe, 2014).

The target group of the programme were in-service teachers. The design of training courses and material for adult learners is challenging. In the elaboration of the program "Arete catalyst', the principles of adult learning were taken into account (Knowles, Holton, \& Swanson, 2005): teachers are professional leaders of teaching processes, who were asked to bring their experience and knowledge to the programme; in the programme design, participants were given place for sharing their ideas, opinions, and knowledge, which enriched the overall quality 
of the learning process; in addition, adults often are decision-makers and selfdirected learners, and therefore, in this teacher training programme design, the trainer was conceived as a 'guide on the side' rather than a 'sage on the stage'; the program also took into account that adult learners need flexibility in the delivery of the training, and that they also are particularly motivated by their own 'generative themes, i.e., the concerns and issues that are most important in a person's life.

Considering the importance in adult learning of personal motivation and emotional well-being, five principles for instructional design that promote adaptive learners' motivation and emotion (Linnenbrink-Garcia, Patall, \& Pekrun, 2016) were also embedded in the programme design, namely: supporting participants' feelings of competence, enhancing autonomy, using personally relevant and active tasks, emphasizing learning over social comparison, and encouraging feelings of belonging.

Educational design is wide field of research (McKenney \& Reeves, 2018; Kelly, Lesh, \& Baek, 2014). Moreover, the process of designing a new educational programme itself can be characterized as a research process. Recent scientific literature on instructional design adopts a problem-solving approach, which is similar to the research process (Romiszowski, 2016). In this perspective, the process of programme design was conceptualized as a path from a 'training problem' to a 'training solution' (Van Merriënboer \& Kirschner, 2017), and the research questions were formulated in terms of which instructional design will better address the educational problems detected in the preliminary research. In this paper the elaboration of the teacher training programme "Arete catalyst" is presented as a research process that uses a specific methodology for answering the research questions.

Design-based implementation research (DbIR) (Fishman, Penuel, Allen, Cheng, \& Sabelli, 2013) is an emerging user-centred research model for the design of educational interventions which emphasizes the ethical values of direct and indirect stakeholders throughout an iterative design process. The principle of DbIR is that researchers and practitioners meet in presence or virtually for sharing knowledge and generating context-sensitive new knowledge about how to integrate values in future practice. A feature of this approach, which made it most appropriate for the design of our teacher training programme, is the continuous engagement of practitioners and researchers at all the parts of the process: the definition of the research design, the formulation of research questions, gathering and analysing data, and interpreting the research results. 
SOCIETY. INTEGRATION. EDUCATION

Proceedings of the International Scientific Conference. Volume V, May $22^{\text {th }}-23^{\text {th }}, 2020.72-88$

\section{Methodology}

\section{Research questions}

The focus of this paper was on the research process that led to the formulation of the learning outcomes and to the definition of the basic structure of the programme. The elaboration of the concrete learning activities and the assessment procedures of the programme were out of the scope of this work. The research questions guiding our inquiry were:

1. What are the challenges that a teacher training programme for character education should address, taking into consideration international experiences and national contexts?

2. What are the learning outcomes which will be useful for addressing those challenges?

3. What is the most appropriate structure of a programme intended to achieve those learning outcomes?

\section{Participants}

Thirty five experts (educational researchers, programme developers, school teachers and headmasters, policy makers, educational supervisors) from seven institutions joined their efforts in order to elaborate an innovative training programme for supporting teachers who desire to be "catalyst" for introducing innovative character education practices at their schools. The selection of partners was based on their capacity to influence education, their experience of working with schools, their ability to engage other relevant stakeholders, and their experience in the field of character education. The final team of partners was well balanced, participants presenting both common characteristics and a rich diversity.

\section{Chronology of the elaboration}

The preparatory phase included extensive communication between partners to refine the project aims and work plan, using individual telephone conversations, email exchange, and on-line videoconferences with all partners. Two face-to-face meetings were also organized in Asturias (Spain) (November 2016) and in Estonia (December 2016). During this preparatory phase, the key roles and responsibilities of the partners involved were defined.

For the elaboration of the programme, at the beginning of the project (December 2017) a kick-off meeting was held in Latvia with the participation of all partners for enhancing synergy, mutual knowledge and defining collaboration channels and responsibilities. In January 2018, a 3-days long technical workshop was held in Asturias (Spain), where academic partners and regional authorities decided the methodology to be used during the preliminary research, which was implemented from January till June 2018. The main goal of the preliminary research was to gain knowledge about the national and international contexts of 
character education and to benchmark the initiatives of teacher training already existing around the world. In June 2018, a second technical workshop took place in Latvia, with the participation of all partners, for discussing the results of the preliminary research (Arete Catalyst, 2018) and setting up the process of designing the teacher training programme. From July 2018 till December 2018 the learning outcomes and general structure of the programme were finalized.

\section{Research design and methods}

The methodology used in the project included three steps: preliminary research; definition of the learning outcomes; and elaboration of the programme structure (Hamza, 2012). The first step for designing the programme was a preliminary research implemented by academic partners in close collaboration with regional authorities in each country. It addressed the contexts of character education in the partner countries and looked for information about the different understandings of character education and the existing initiatives (programmes, teaching methodologies and teacher training). On these bases, a SWOT analysis of character education in each country and a joint benchmarking of teacher training initiatives worldwide were performed. Case studies of good practices were also implemented in each partner country.

The methodology used during the preliminary research included online desk research of character education programmes and teaching methodologies; desk-analysis of existing teacher training programmes in each country; and webbased benchmarking of best practices on character education. For investigating the case studies, in-site visits and interviews with headmasters, teachers and pupils were organized at the chosen school. The preliminary research ended with a synthesis about the desirable general features of a teacher training programme for character education at school (Arete Catalyst, 2018). An expert seminar, with the participation of teachers, career consultants and school principals, was also organized at the beginning of the technical workshop in Latvia in June 2018 for discussing the results of the preliminary research.

The second step was the definition of the learning outcomes of the programme. Design-based implementation research (Fishman et al., 2013) was used for aligning the learning outcomes and the structure of the programme (Biggs, 1996): based on the initial ideas discussed during the preparatory phase and on the results of the preliminary research, an initial set of intended learning outcomes and a provisory programme structure aligned with them was proposed as starting point for discussion during the second technical workshop in Latvia in June 2018. Thirty participants (teachers, academics, educational experts, external advisors, regional authorities) from the three partner countries worked on three groups. Each group explored independently the initial proposal and elaborated suggestions for improving the formulation of the learning outcomes and of the general structure of the programme. After that, during a general 
session, each group presented its opinion about the learning outcomes and the related programme structure, and the proposals were jointly discussed. A consensus on six main domains of learning outcomes was reached, and several formulations for the learning outcomes relating to each domain were proposed and discussed. A consensus was also reached regarding the structure of the program: the main modules and the kind of activities that could be included in each module. At the end of the technical workshop the scientific adviser of the project summarized all the accepted proposals and elaborated a final version of the learning outcomes and of the programme structure, which was sent to all participants for refining the final formulation.

\section{Research Results}

In this section firstly the results of the preliminary research (Arete Catalyst, 2018) and then the learning outcomes, the structure and the main features of the programme will be presented.

\section{Inputs from the preliminary research on the teacher training programme}

Regarding the challenges that a teacher training programme for character education should address (first research question), three inputs were obtained from the preliminary research: the gaps that the teacher training programme should address were clarified; good practices were discovered during international benchmarking and integrated in the programme; and recommendations from the experts' seminar were considered.

\section{Gaps in teacher training initiatives to be addressed by the programme}

Several gaps were detected in the participant countries regarding the initiatives for teacher training in the field of character education. Overall, the teacher training initiatives in Latvia currently address only partially the different aspects of the field of character education: some initiatives are theory-oriented, other are oriented to the classroom work, or focus on concrete subject matters (e.g., literature), some focus on a concrete group of virtues (e.g., civic virtues, patriotism), others - on the integration of values in the school life or on interdisciplinary aspects of character education. It was found that there is a need for a teacher professional development programme in Latvia (Surikova \& Pigozne, 2018; Fernández González, 2019) that integrates the four teacher training aspects the Latvian Education Law (1998) refers to: 1) improvement of teachers' self-experience in the field, 2) enhancement of communicative competence for creating a school culture, 3) elaboration of methodical and didactic materials, and 4) school and class management. Several teacher training programmes are being proposed in the field of virtue education, but they have an 
episodic character: for example, the seminars "Improvement of a teachers' professional competence on the issues of national and virtue education", "Improvement of virtues in the upbringing process", and "Basic principles of successful upbringing within the aspect of value and virtue education", implemented in 2017-2018, lasted only 6 hours or less (Surikova \& Pigozne, 2018).

In Spain, teacher training for character education is done mostly from the perspective of developing pupils' mutual respect and tolerance, but courses related to education for coexistence and education in values remain optional in teacher training curricula. The regional 'Continuous teacher training plan', which is intended to improve the scientific, didactic and professional preparation of teachers, includes several priority lines related to character education, such as teachers' preparation for enhancing coexistence in the educational centres and preventing bullying, and enhancing teachers' ability of developing didactic materials in this field. Some concrete teacher training methodologies, such as the 'pedagogical gatherings' at school level, and working groups of methodological innovation at municipality level, are put forward, bet have not yet reached a wide dissemination (Arete Catalyst, 2018).

In Estonia, teacher training related to character education adopts the perspective of P4C, teacher ethics and value education. The Estonian national programme "Value development of Estonian society" which was initially implemented in 2009-2013 and then continued for 2015-2020, included several teacher training activities: for example, a game for teachers for discussing values was developed, introduced and practiced in the teacher training sessions, and a book describing four active learning methods promoting value education for different ages in educational organisations was published. Numerous in-service training courses for value education were developed through an annual inservice training programme. And materials for addressing value education in teacher education were elaborated within the programme "Development of teachers' value education competencies in teacher training”. However, this educational offer is not sufficient to prepare adequately the future teachers (Schihalejev, 2011).

\section{Good practices revealed during the international benchmarking}

Nowadays many international and national projects address pupils' character education from different perspectives (Fernández González, 2018). Efforts have been done also in the field of teacher training for character education. In the UK, there are a number of initiatives for teachers' professional competence development in this field. For example, in 2016, the School of Education at the University of Birmingham introduced the world first online 
MA programme in Character Education, which is taught by expert members of the Jubilee Centre for Character and Virtues. Short online courses are also available for free, such as "Building character through youth social action" and "What is character? Virtue ethics in education". In the USA, there are also a multiplicity of courses for teachers' professional competence development in character education. For example, Character.org offers multiple support and training opportunities for schools, districts, and state-wide initiatives, which range from one day seminars to multi-year assistance.

Personality development has often been addressed from the lens of P4C and mindfulness, and there is a number of teacher training initiatives in these fields. For example, DialogueWorks (UK) encourages pupils to focus on carefully chosen personal and social virtues that will help them most in their learning and their lives. The practical training for teachers includes a two-day foundations course, a two-day advanced training in philosophical teaching, and a one-day course showing teachers how to build pupils' skills in the metacognitive framework. The programme SAPERE (UK) provides teacher training in P4C, in order to encourage children to think critically, creatively, collaboratively and caringly in order to become lifelong learners. The teacher training programme includes a foundation course and several advanced courses of two or three days for examining the nature, purpose and methods of philosophical enquiry, showing how to choose and create materials to stimulate deeper thinking, explaining how P4C can impact the school's standards and values, and showing how to plan a progress in P4C across curriculum. The programme "Akademie Kinder Philosophieren" (Germany) offers courses for teachers and parents. The foundational course for teachers consists of four two-days modules (all together eight days and 64 hours), focussing on different questions (who am I? Me and others; what is the world? what are values?). The programme "Akademie Philosophieren mit Kindern und Jugendlichen" (Austria) focus on philosophizing with big groups of children, or with a team of colleagues or parents. However, there is a lack of programmes focussing on training teachers for implementing holistic character education at school.

Once the different good practices were analysed and compared, the following ones were retained for the design of the programme "Arete catalyst":

- The programme DialogueWorks (UK), which set a strong theoretical and philosophical foundations for their course.

- The programme SAPERE (UK), which offers a very clear structure for the courses, focusing on the learner becoming an expert in the field. This programme is also clear about the importance of practice for acquiring understanding of character growth. 
- The mindfulness courses, which provided insights about the importance of including different levels of expertise in the teacher training programme for character education, and also offered examples of exercises and the content of courses.

- The P4C courses from Germany and Austria, which were good examples of how the course structure should be developed and what to take into account when deciding about the contents. An important idea used in these courses is that there should always be a 3-4 weeks gap time between meetings, so that pre-service teachers are able to practice the lessons learnt and to discuss their experience with other teachers. Organizing meetings over a longer period of time helps participants to transform practice into a consistent professional habit. Another important aspect is the practical approach of the teacher training course: teachers have to be able to take part in philosophical discussions and should experience by themselves the impact the discussions have on them. Another useful idea was that at the end of course each participant carried out a planned discussion with other participants (as an examination).

\section{Recommendations of the experts' seminar}

A seminar with educational experts was organized in June 2018 in Latvia during the technical workshop. The work done during the first months of the project was presented to them and a joint discussion about the design of the teacher training programme "Arete catalyst" took place together with project participants. The main suggestions proposed during this seminar were summarised (Arete Catalyst, 2018) as follows:

- About the contents of the programme: Teachers need to acquire personal experience and understanding of their own values and virtues, obtained through personal and group reflection. A multicultural perspective is necessary. Mindfulness exercises, which enhance awareness and an open (non-judgemental) attitude, would be desirable to work on teachers' self-knowledge and own values.

- $\quad$ About the programme materials: Teachers need support to elaborate materials to implement character education in the classroom. Considering that many classroom materials are available online, the programme should show catalyst teachers where these resources are and should include practical workshops about how to adapt those materials to their local and classroom contexts. 
- About programme methodology and assessment: Considering that schoolteachers often feel saturated, the programme should build on the materials teachers have already elaborated for their own lessons, upgrading them by including in their worksheets or presentations some questions related to character education. The delivering of the programme should be flexible, and the methodology should be innovative, including blended learning and the use of virtual spaces, collaborative activities and peer assessment. The programme should be very practical.

- About the school community: A priority of the programme should be to involve the educational community as a whole. To be sustainable, the administration of the school should support strongly the introduction of character education. Parents and pupils should also be involved in the design of the programme at school level and in the choice of values/virtues to focus on.

- About terminology: Values and virtues are similar concepts but not identic. Clarification of the meaning of these terms should be included in the programme. Regarding country specificities, in Latvia it might be better to use the term 'education of moral habits' instead of 'character education' or 'virtue education'. In Estonia the term 'value education' is widely accepted and, with the appropriate explanations, could cover also 'virtue education'. In addition, the term vaikuseminutid is being used as a synonym of 'mindfulness'. In Spain (Asturias), the most appropriate would be to use the perspective of education for coexistence for addressing character education at school.

- The teacher training programme should include common transnational elements, but also should take into account country specificities (Arete Catalyst, 2018, 46).

These inputs strengthened the rational for the formulation of the learning outcomes and the choice of the programme structure, which are presented below.

\section{The learning outcomes of the programme}

Regarding the second research question, the learning outcomes of the programme were defined based on the preliminary research and following the process explained in the methodology section. Six compulsory domains were defined, and one or two learning outcomes were formulated for each domain (Table 1). 
Table 1 Six compulsory domains of learning outcomes

\begin{tabular}{|l|l|}
\hline \multicolumn{1}{|c|}{ Domain } & \multicolumn{1}{c|}{ Learning outcomes } \\
\hline $\begin{array}{l}\text { Advanced } \\
\text { disciplinary } \\
\text { knowledge and } \\
\text { practices }\end{array}$ & $\begin{array}{l}\text { Graduates will have acquired advanced knowledge and skills in the } \\
\text { fields of value and virtue education and development of transversal } \\
\text { competences, and an ability to evaluate them critically in the context of } \\
\text { their country and school. }\end{array}$ \\
\hline $\begin{array}{l}\text { Self-awareness and } \\
\text { cognitive skills }\end{array}$ & $\begin{array}{l}\text { Graduates will have developed advanced awareness of and critical } \\
\text { thinking about their own values and virtues, and those of their } \\
\text { educational community. }\end{array}$ \\
\hline $\begin{array}{l}\text { Methodological and } \\
\text { didactic skills }\end{array}$ & $\begin{array}{l}\text { Graduates will have acquired the knowledge and skills necessary for } \\
\text { selecting/elaborating materials for the classroom, for a lesson or for } \\
\text { integrating value/virtue education transversally through their subject. } \\
\text { They will be able to use them in the classroom and evaluate them. }\end{array}$ \\
\hline $\begin{array}{l}\text { Communication, } \\
\text { adaptive and } \\
\text { interactional skills }\end{array}$ & $\begin{array}{l}\text { Graduates will be able to communicate effectively to a range of } \\
\text { audiences (school administration, other teachers, parents, pupils). }\end{array}$ \\
\hline Practising values & $\begin{array}{l}\text { Graduates will have developed an understanding of the importance of } \\
\text { practising values inside a community for developing character skills and } \\
\text { good habits. They will be able to demonstrate this knowledge together } \\
\text { with others during a project with a social dimension. }\end{array}$ \\
\hline $\begin{array}{l}\text { Transformative } \\
\text { skills }\end{array}$ & $\begin{array}{l}\text { Graduates will have developed the ability of conceptualizing and } \\
\text { formulating a proposal adapted to their school situation for the creation } \\
\text { of a school culture that supports value and virtue education, involving all } \\
\text { educational actors }\end{array}$ \\
\hline
\end{tabular}

Source: Arete Catalyst, 2019, 7-8

The developers of the program decided that all the 6 domains are nonnegotiable and should be covered by the programme, but the concrete formulation of the learning outcomes is negotiable at the beginning of each programme implementation: the learning outcomes can be discussed with the participants, and emerging learning outcomes can be added at the beginning or during the implementation of the programme.

\section{Programme structure and features}

The third research question addressed how the programme should be structured for supporting the achievement of those learning outcomes. It was found that the programme should include 3 learning modules, an external project and a final assignment (Fig. 1). 
SOCIETY. INTEGRATION. EDUCATION

Proceedings of the International Scientific Conference. Volume V, May $22^{\text {th }}-23^{\text {th }}, 2020.72-88$

Figure 1 General structure of the programme (Arete Catalyst, 2019, 6)

\begin{tabular}{|l|l|l|l|l|}
\hline Programme name & & ARETE CATALYST \\
\hline Programme sections & LEARNING MODULES & $\begin{array}{c}\text { EXTERNAL } \\
\text { PROJECT }\end{array}$ \\
\hline Sections details & Theory & Communication & Methodology & $\begin{array}{c}\text { In a team } \\
\text { External \& Social }\end{array}$ \\
\hline Assessment & $\begin{array}{c}\text { Understandings } \\
\text { Practices \& Proposals }\end{array}$ \\
\hline
\end{tabular}

Regarding the learning modules, the first module aims at the enhancement of teacher's theoretical and applied knowledge of the field, and of teacher selfawareness about their own values and virtues. The second module aims at the enhancement of teacher's communicative skills for the transformation of the school culture: definition of school values, work with parents, teachers and administration. The third module aims at the enhancement of teachers' methodological competence by designing activities and materials and piloting them in the classroom.

The 'external project' should fulfil 3 conditions: 1) it should be implemented in a team (together with other catalyst teachers attending the programme, or with teachers and/parents of their school, or with pupils); 2) it should have an external dimension (it should be implemented out of the settings where the group comes from); and 3) it should have a social dimension, addressing people with different needs (loneliness, illness, ageing, migrants, vulnerable youngsters, people with different dependences, etc.).

For the final assignment, participants in the programme have to create a digital portfolio collecting/summarizing the contents of the course, which will have a practical utility for the teacher. It should include a section 'Action proposal for my school'. The portfolio could have the following sections:

a) Understandings of virtues and values. this section can include several sub-sections: my values and virtues; my school values and virtues; international perspectives; theoretical bases (academic papers).

b) Practical materials. this section can include several sections: materials for classroom hours; teaching values and virtues through subjects; description of social projects; materials for working with families and school administration, etc.

c) Action proposal for my school. A practical and realistic proposal for transforming the teachers' whole school culture. This proposal can 
have several sections: general aims, context analysis (opportunities, difficulties at school), steps to implement, necessary resources, etc. (Arete Catalyst, 2019, 7).

The programme “Arete catalyst' includes some common (fixed) elements, which confer a unitarian identity to the programme, and some flexible elements, for allowing its adaptation to different settings/countries (Table 2).

Table 2 Fixed and flexible elements of the programme

\begin{tabular}{|c|c|c|}
\hline Aspects & Common elements & Flexible elements \\
\hline $\begin{array}{l}\text { Name of the } \\
\text { programme }\end{array}$ & “Arete catalyst” & Can have "national subtitles". \\
\hline Target public & In-service teachers (catalyst teachers) & $\begin{array}{l}\text { Can be implemented for different } \\
\text { teachers, or within a single school. }\end{array}$ \\
\hline $\begin{array}{l}\text { Academic } \\
\text { workload }\end{array}$ & 32 hours (incl. independent work) & $\begin{array}{l}\text { Programme timeline can vary. } \\
\text { The number of contact hours can } \\
\text { vary. }\end{array}$ \\
\hline $\begin{array}{l}\text { Programme } \\
\text { structure }\end{array}$ & $\begin{array}{l}3 \text { learning modules, an external project } \\
\text { and a final assignment }\end{array}$ & $\begin{array}{l}\text { Order of modules can vary. } \\
\text { Hours per module can vary. } \\
\text { Order and duration decided before } \\
\text { starting. }\end{array}$ \\
\hline $\begin{array}{l}\text { Intended learning } \\
\text { outcomes (ILOs) }\end{array}$ & Six compulsory domains of ILOs & $\begin{array}{l}\text { The formulation of the ILOs within } \\
\text { each domain can vary. } \\
\text { Emerging ILOs can be added. }\end{array}$ \\
\hline Learning activities & $\begin{array}{l}\text { Described using a common template. } \\
\text { Aligned with ILOs. } \\
\text { Three kinds of activities to be included } \\
\text { (reflective, practical, planning). } \\
\text { The activity set should sum } 32 \text { hours. }\end{array}$ & $\begin{array}{l}\text { Set of activities decided before } \\
\text { launching according to ILOs. } \\
\text { Local implementation can vary } \\
\text { from the description file. }\end{array}$ \\
\hline $\begin{array}{l}\text { Supplementary } \\
\text { materials }\end{array}$ & Details in the activity description file. & Supplementary materials can vary. \\
\hline Assessment & $\begin{array}{l}\text { Details in the activity description file. } \\
\text { Assessment refers to the programme } \\
\text { ILOs. }\end{array}$ & Assessment modalities can vary. \\
\hline
\end{tabular}

Source: Arete Catalyst, 2019, 9

\section{Discussion}

In this discussion, the benefits obtained during the programme elaboration and the expected impact of the programme will be addressed.

The joint elaboration of the project had a positive impact on participants' professional development: it enhanced their motivation and satisfaction in daily work, and enhanced their own transversal competences, such as the ability to use practically foreign languages. The methodology used also helped participants to develop collaborative skills. It also provided them a better understanding of practices, policies and systems in education across the participant countries. 
The project had also positive effects on the participating organisations. They increased their capacity to work at international level and reinforced their professionalism in cooperating with other countries. They also increased their capacity of addressing new target groups (teachers, school staff, parents), by offering them an attractive teacher training programme in line with their concrete needs and expectations. Participant schools developed a school culture more sensitive to character education and improved their school networking.

This process also reinforced the interaction between practitioners, researchers and policy makers. The process of elaboration of the programme "Arete catalyst" was a good example both of integration of research and design of educational programmes, and of interdisciplinarity approach, integrating different branches of science (educational sciences, psychology, philosophy, ethics and religion). The transnational character of the elaboration process enhanced a joint reflection and a novel and culturally sensitive approach to the development of pupils' character and transversal competences.

The final version of the teacher training programme is available in English, Latvian, Spanish and Estonian on the website of the project "Arete Catalyst" (www.aretecatalyst.me). The programme is being piloted at national level, and the results will be discussed to improve the quality of the programme.

In the future, the implementation of the teacher training programme "Arete catalyst" would strengthen the professional profile of teachers, enhancing their continuing professional development in the field of pupils' transversal competences and personality development. The knowledge and skills included in the learning outcomes of the programme will strengthen schoolteachers' leadership. In the long term, the work of catalyst teachers graduating the programme "Arete catalyst", who will be experts in character education at school, is expected to have also a positive impact at systemic level, by the modernisation and reinforcement of the response of education to the main challenges of today's world: promotion of social, civic and intercultural competences, intercultural dialogue, democratic values and fundamental rights, and active citizenship.

\section{Acknowledgements}

The research presented in this article was founded by the Erasmus+ project "Supporting teachers for developing intra-personal competencies and character education at school - Arete Catalyst" (2017-2019), project number 2017-1-LV01-KA201-035435, by the European Regional Development Fund within the post-doctoral project "Arete school” (2017-2020), project number 1.1.1.2/VIAA/1/16/071, and by the University of Latvia within the research project "Human, technologies and quality of education" (2016-2019) conducted at the Faculty of Education, Psychology and Art. 
González et al., 2020. Designing a Teacher Training Programme for Character Education: an International Partnership

\section{References}

Arete Catalyst. (2018). A needs analysis report: Mapping of teachers' practices and expectations in the field of pupils' intrapersonal competencies and character education in Latvia, Estonia and Spain (Intellectual output No 1). Retrieved from https://www.pzi.lu.lv/fileadmin/user_upload/lu_portal/projekti/pzi/ARETE/Arete_Catal yst_Report_EN.pdf

Arete Catalyst. (2019). “Arete catalyst”: Teacher training program for enhancing pupils' flourishment at school (Intellectual output No 2). Retrieved from https://www.pzi.lu.lv/ fileadmin/user_upload/lu_portal/projekti/pzi/ARETE/Arete_Catalyst_Programme_EN.pdf

Arthur, J., Davison, J., \& Lewis, M. (2005). Professional values and practice: Achieving the standards for QTS. Oxon: Routledge Falmer.

Arthur, J., Fullard, M., Watts, P., \& Moller, F. (2018). Character perspectives of student teachers. Birmingham: University of Birmingham, Jubilee Centre for Character and Virtues. Retrieved from http://www.jubileecentre.ac.uk/userfiles/jubileecentre/pdf/ Research\%20Reports/18002_LowRes.pdf

Biggs, J. (1996). Enhancing teaching through constructive alignment. Higher education, 32(3), 347-364.

Campbell, E. (2008). Review of the literature: The ethics of teaching as a moral profession. Curriculum Enquiry, 38(4), 357-385.

Carr, D. (2007). Character in teaching. British Journal of Educational Studies, 55(4), 369-389.

Chell, E., \& Athayde, R. (2011). Planning for uncertainty: soft skills, hard skills and innovation. Reflective Practice, 12(5), 615-628.

Daniela, L., Nīmante, D., \& Kraǵe, G. (2014). Development of support system for decreasing social exclusion. In Daniela, Lūka, Rutka, \& Žogla (Eds.), Teacher of the 21st Century: Quality Education for Quality Teaching (pp. 1-13). Newcastle upon Tyne, Cambridge Scholar Publishing.

Education Law. (1998). Retrieved from https://likumi.lv/ta/en/en/id/50759-education-law

Dreikurs, R.M., Grunwald, B.B., \& Pepper, F.C. (1998). Managing sanity in the classroom. Philadelphia: Accelerated Development.

Dreikurs, R., Cassel, P., \& Ferguson, E.D. (2004). Discipline without tears: How to reduce conflict and establish cooperation in the classroom. Toronto: Wiley.

Fernández González, M.J. (2018). Research-based reflections about character education: myths, challenges and international perspectives. Society. Integration. Education. Proceedings of the international scientific conference. Rezekne (Latvia) May 25-26, 2018 Volume II (pp. 126-136). Latvia: RTA izdevniecība.

Fernández González, M.J. (2019). Skolēnu morālā audzināšana Latvijas skolās: vecāku, skolotāju, topošo skolotāju un skolu un izglìtības pārvalžu vadītāju viedokḷi. Populārzinātniskais pētījuma ziņojums [Moral Education of Pupils in Latvian Schools: The Views of Parents, Teachers, Future Teachers, Heads of Schools and Education Boards. Popular Science Research Report]. Rīga: LU PPMF Pedagoğijas zinātniskais institūts. Retrieved from http://dspace.lu.lv/dspace/bitstream/handle/7/46498/Zi\% 20ojums_Skol\%20nu\%20mor\%201\%20\%20audzin\%20\%20ana\%20Latvijas\%20skol\% 20s.pdf?sequence $=1$

Fishman, B.J., Penuel, W.R., Allen, A.R., Cheng, B.H., \& Sabelli, N.O.R.A. (2013). Designbased implementation research: An emerging model for transforming the relationship of research and practice. National Society for the Study of Education, 112(2), 136-156. 
SOCIETY. INTEGRATION. EDUCATION

Proceedings of the International Scientific Conference. Volume V, May $22^{\text {th }}-23^{\text {th }}, 2020.72-88$

Hamza, M. (2012). Developing training material guide. Swedish Civil Contingencies Agency (MSB).

Kelly, A.E., Lesh, R.A., \& Baek, J.Y. (Eds.). (2014). Handbook of design research methods in education: Innovations in science, technology, engineering, and mathematics learning and teaching. Routledge.

Knowles, M., Holton, E., \& Swanson, R. (2005). The adult learner: The definitive classic in adult education and human resource development. Burlington, MA: Elsevier.

Linnenbrink-Garcia, L., Patall, E.A., \& Pekrun, R. (2016). Adaptive motivation and emotion in education: Research and principles for instructional design. Policy Insights from the Behavioral and Brain Sciences, 3(2), 228-236.

McKenney, S., \& Reeves, T.C. (2018). Conducting educational design research. Routledge.

Ogden, T., \& Sørlie, M.A. (2009). Implementing and evaluating empirically based family and school programmes for children with conduct problems in Norway. International Journal of Emotional Education, 1(1), 96-107.

Osguthorpe, R.D. (2013). Attending to ethical and moral dispositions in teacher education. Issues in Teacher Education, 22(1), 17-28.

Romiszowski, A.J. (2016). Designing instructional systems: Decision making in course planning and curriculum design. Routledge.

Rosenberg, G.R. (2018). Moral agency as teaching morally and teaching morality. In Harrison \& Walker (Eds.), The Theory and Practice of Virtue Education (pp. 112-125). Oxon: Routledge.

Sanger, M.N. (2012). The schizophrenia of contemporary education and the moral work of teaching. Curriculum Inquiry, 42(2), 285-307.

Säre, E., Luik, P., \& Tulviste, T. (2016). Improving pre-schoolers' reasoning skills using the philosophy for children programme. TRAMES, 20(3), 273-295. Retrieved from http://www.eap.ee/public/trames_pdf/2016/issue_3/trames-2016-3-273-295.pdf

Säre, E. (2018). Developing the reasoning skills of pre-schoolers through philosophy for children. University of Tartu. Retrieved from http://dspace.ut.ee/bitstream/handle/ 10062/59911/sare_egle.pdf

Schihalejev, O. (2014). Religious education at schools in Estonia. Religious education at schools in Europe, 10, 75-104.

Sharp, A.M., Reed, R.F., \& Lipman, M. (2010). Studies in philosophy for children: Harry Stottlemeier's discovery. Temple University Press.

Surikova, S., \& Pigozne, T. (2018). Transversal competences and character education in Latvia: A needs analysis report. Retrieved from https:/dspace.lu.lv/dspace/handle/ $7 / 49011$

The Jubilee Centre for Character and Virtues. (2015). Statement on teacher education and character education. Birmingham: University of Birmingham, Jubilee Centre for Character and Virtues. Retrieved from http://www.jubileecentre.ac.uk/userfiles/ jubileecentre/pdf/character-education/Statement_on_Teacher_Education_and_\%20 Character_Education.pdf

The Jubilee Centre for Character and Virtues. (2017). A framework for character education in schools. Birmingham: University of Birmingham. Retrieved from http://jubileecentre. ac.uk/userfiles/jubileecentre/pdf/other-centre-papers/Framework.pdf

Van Merriënboer, J.J., \& Kirschner, P.A. (2017). Ten steps to complex learning: A systematic approach to four-component instructional design. Routledge. 